\title{
Livestock policies and red meat sector: Republic period and ensuing years*
}

\section{Review Article}

Volume: 3, Issue: 3 December 2019

Pages: $64-74$

\section{Engin Sakarya, Arzu Gökdai, Tuğba Sarıhan Şahin}

Department of Animal Health Economics and Management, University of Ankara, Turkey Sakarya E.: ORCID: 0000-0003-3569-3292; Gökdai A.: ORCID: 0000-0002-5509-2171; Şahin T.S.: ORCID: 0000-00017364-6230

\section{Article History}

Received: 30. 09.2019 Accepted: 04.12.2019 Available online: 13. 12.2019

\begin{abstract}
Implementation of policies aimed at agriculture and animal husbandry, agricultural supports are used as an important tool. Since the proclamation of the Republic, livestock sector of Turkey has entered into a number of changes and improvements. The data used in this study were collected from Turkey Statistical Institute (TURKSTAT), reports of drafting convention in sector, the five-year development plans and literature. It has been determined that there is not enough share from the subsidies within the agricultural policies applied in the livestock sector in terms of periods. Support for the sector was also insufficient in terms of credit and financing supply in animal husbandry. It was observed that there was no significant development in animal production in planned development periods. In macroeconomic planning of the sector, input-output relationship could not be considered on a sectoral basis according to the development goals. It has been seen that technical and economic integration such as health, breeding, production, cultivation, fattening and product evaluation is not taken into consideration adequately in planning. Today, the most important problem of the sector is high quality, sufficient roughage and concentrate feed supply and low yield per unit animal. However, real policy in supporting livestock should ensure that product / feed price ratios to maintain profitability in production. In order to achieve a certain increase in animal production, the support provided by the state and the price policy are important. Price policy has an important share in increasing production both in quantity and quality. The enterprises operating in animal husbandry are under the economic grip of the sellers and buyers, who are limited in number during the production stage. In this respect, the organization of the producer and the development of the marketing infrastructure, support and encouragement by the state may play an important role in solving the problems.
\end{abstract}

Keywords: livestock policies, red meat, productivity, organization, marketing

DOI: 10.30704/http-www-jivs-net.627099

To cite this article: Sakarya, E., Gökdai, A., \& Şahin, T. S. (2019). Livestock policies and read meat sector: Republic period and ensuing years. Journal of Istanbul Veterinary Sciences. 3(3), 64-74, Abbreviated Title: J Ist Vet Sci

*The part of this paper was presented at the International VETEXPO Veterinary Science Congress in September 20-22, 2019, İstanbul/Turkey.

\section{Introduction}

There is an extensive and intensive intervention of the state in agriculture and animal husbandry both in underdeveloped and industrialized advanced economies. Product, price and income instability and low elasticity of demand in the sector have made policy measures widespread which don't differ from each other. In industrialized economies, the main issue in

*Corresponding Author: Arzu Gökdai

E-mail: agokdai@ankara.edu.tr terms of long-term agricultural policy is to take the necessary measures to prevent the decreasing product prices and producer incomes in consequence of the increase in agricultural and animal production and imports. In developing countries such as Turkey, the development of policies aimed at increasing production and regulation of markets have priority (Kazgan, 1977). 
In addition to its important role in national nutrition, livestock sector in our country; has undertaken many economic functions such as providing raw materials to industry, increasing exports, achieving the stability between the region and sectors in balance, preventing hidden unemployment and migration in rural areas and creating new employment opportunities in industry-services sectors.

Livestock sector of our country has gone through several changes and developments in consideration of all the developments and changes in the world from the proclamation of the Republic until today. In this study, policies implemented in the livestock sector in Turkey were examined into periods as; 1923-1950, 1950-1960, 1960-1980 and after 1980.

\section{Period of 1923-1950}

In the first years of the Republic, Turkey was lagging behind in terms of industrial aspect in consequence of war, and about $80 \%$ of the country's population were living in villages and towns. At the same time, many sectors (trade, transportation, banking, etc.) were monopolized by foreign capital (HAYGEM, 2015). In this period, Mustafa Kemal Atatürk, who was aware of the fact that political independence could be achieved by obtaining economic independence, convened the I. Economic Congress on February 17, 1923, to determine the financial measures to be taken in the process of transition to an independent economy. In congress, restructuring decisions have been taken aimed at integrating our country with contemporary world conditions which were extremely important in terms of the national economy and history. An important consequence of this congress was the establishment of industrial branches which supply raw materials domestically and so that initiation of development based on equities (TUiK, 2019).

In the period following the proclamation of the Republic, it is seen to be a current number of animals in Turkey were decreased by reason of war and outbreak of animal diseases experienced in previous years. For example, in the agricultural census of 1912 year, 7 million head of cattle, calculated as 4 million head in 1927 and 19 million head of sheep had fallen to 10 million head (TUIK, 2019).

It is obvious that there are specific measures to be taken in this regard in a country whose economy is largely based on agriculture and animal husbandry. Therefore, the necessity of establishing an organization came to the fore in order to redevelop the animal husbandry, which has declined due to various periodical elements in this time. Accordingly, the Branch Office of Animal Production was established primarily within the scope of the Ministry of Economy in 1923. In 1924, the Ministry of Economy was divided into two sections as the Ministry of Agriculture and the Ministry of Trade, so studies related to animal husbandry were began to carry out by the Ministry of Agriculture. Moreover, it is understood that the public services concerning the rural sector should be carried out in a sectoral public organization structure. In this context, since it was aimed to increase the efficiency of services and reduce costs by determining clearly the authorities and responsibilities in public services, the General Directorate of Agricultural Affairs, Veterinary Affairs and Forestry were established in 1937 with the Law No. 3202 named as Duties and Organization of Agriculture Ministry of Agriculture (Cevger et al., 2011).

Considering the importance of the livestock sector in terms of Turkey's economy, studies focused on improvement of animal breeding on existing animals have also begun in this period. It is aimed to produce and distribute qualified breeding animals to the public by improving the quality of the existing animal potential with the Animal Breeding Law No. 904 enacted in 1926. In this period, 15 animal breeding institutions were established, such as stud farms, pens, and trial farms. Besides, breeding animals' imports have been done by these institutions for the purpose of using them in cattle, sheep and horse breeding studies and distribution to the public (TUiK, 2019).

The economic crisis, which emerged with the end of World War I, affected the whole world, later on, especially Germany and the USA. Agricultural product prices decreased in Turkey, and also currency depreciation occurred in Turkish Lira, and the foreign trade deficit increased, especially between the years 1928-1932 like many other countries. As a result of the economic crisis, a step has been taken towards supporting agricultural products in Turkey for the first time, and with the "Wheat Protection Law" enacted in 1932 support purchases have been made by Ziraat Bank. While these subsidies continued in agricultural products such as other cereals, tobacco and cotton in the following years, unfortunately, no subsidies were implemented for the livestock subsectors dealing with similar problems (Cevger et al., 2011).

At the Industrial Congress held in 1936, it was planned to establish a public institution to operate in the meat industry. For this purpose, a step was taken for the establishment of the Meat and Fish Institution, which became operational in 1953, and the technical and economic infrastructure and establishment 
studies were started which were required by the institution.

In spite of the global crisis experienced throughout the world, the average increase in the production of animal products (milk, meat and wool) was above $3 \%$ in this period.

In the early years of the Republic, multidimensional studies were conducted to fight against epidemic animal diseases. Modern animal husbandry methods started to be used and also modern methods of fighting against animal diseases were added to curriculum in Veterinary Education due to the intensive pressure of the European countries. A significant amount of allowance has been allocated in the budget in order to increase vaccine production for prophylactic purposes, additions have been made to the number of occupational staff who would work in the fight against diseases, experts have been brought from abroad to carry out studies in our country and also some Turkish experts have been sent to international congresses and meetings about animal breeding and health (Temel, 2015).

Memberships were done to Office International des Epizooties (OIE) and World Veterinary Association. Within the frame of " 5 -year Veterinary Services Program" between 1924-1929, "Animal Breeding Law" in 1926 and "Animal Health and Surveillance Law" in 1928 enacted. Veterinarians have achieved superior success fighting against many diseases, especially in the fight against rinderpest by implementing these practices (Erk, 1973).

Another important development in the sector in this period was enacting the "Agricultural Sales Cooperatives Law" in 1935. Atatürk also gave particular importance to the cooperatives which had an important share in the organization of producers in rural areas.

It is thought that the decrease in production increase rate occurred from 1939 to 1950 was because of the negative environment caused by World War II.

\section{Period of 1950-1960}

Several innovations in terms of Turkey's economic and political structure has occurred as at the beginning of 1950. One of these innovations was the introduction of tractors in Turkey's agriculture sector following World War II. Marshall assistance, which was effective between 1946 and 1950, provided the necessary assistance to the farmers of our country in the point of mechanization in agriculture. Although significant increases in agricultural production have been achieved by this means, unfortunately, these increases have not been mainly due to the increase in yield per decare, but by the destruction and transformation of meadows and pastures to agricultural land which is the main input of animal husbandry and the cheapest source of roughage. Meadow and pasture areas; were 44.3 million hectares in total in 1935, decreased by $15 \%$ to 37.8 million hectares in 1950 and decreased to 28.6 million hectares with a decrease of $35 \%$ in 1960 . So significant deterioration has been shaped in the rural economic structure (TUIK, 2019).

The Meat and Fish Institution was established in 1952 under the leadership of the state and started its activities on January 1, 1953, with the important organizational goals and macro objectives such as rationalization of animal production and economic organization of producers, establishing a stable market structure and leading the establishment of the national meat industry.

Another state economic enterprise named Fleece and Angora Inc. was established in 1955 for the purposes of protecting the benefit of the producers in the fleece and angora marketing in our country, making direct purchases from the producer when necessary and encouraging the production of finegrained fleece. And Feed Industry Inc. was established in 1956, to produce feed, which is one of the most important input elements of the livestock sector, and to promote the production of raw feed materials (Cevger et al., 2011).

In this period, breeding animal imports continued in order to continue cattle breeding activities, but sheep breeding studies could not be carried out with necessary diligence. In the same way, it is understood that the necessary importance was not given to cooperatives.

If the process is evaluated until planned development periods in terms of animal husbandry policies; it can be said that the sector hasn't developed enough to the extent of its potential due to ceiling price application. Nevertheless, in this decade, there was an average annual production increase in products following as; $4.1 \%$ in milk, $6.5 \%$ in meat and $4.6 \%$ in fleece. It is understood that the production increase was basically in consequence of Atatürk's period until 1939 (TUiK, 2019).

\section{Period of 1960-1980}

State Planning Organization was established in 1961 with the objectives as; presenting Turkey's social and economic problems and accordingly conducting applications for national and regional development within the framework of democratic principles desired 
results could not be achieved from I., II. and III. I FiveYear Development Plans prepared by the State Planning Organization in terms of achieving the targeted production levels in livestock and mobilizing the existing potential, and realizations fell behind the plan targets.

One of the key developments occurred in the sector in this period was launching Dairy Industry Institution of Turkey in 1965 with the main objectives such as; development of dairy industry and providing production-industry integration in the sector.

Significant changes greet the eye when numbers of animals examined from the establishment of the Republic of Turkey until today. There was an increase in the number of bovine and ovine animals until World War II. During the war years, the rate of increase has decreased, and the number of some species have decreased, and in the following, period there have been increases in the number of some animals. In the 1980s and beyond, unplanned livestock and meat exports and liberal policies implemented in animal husbandry led to decreases in the number of animals and withdrawal from production (TIGEM, 2018).

\section{Period after 1980}

The period which starts with economic stabilization measures in Turkey implemented on Jan 24th 1980 and transition to the free market economy has led to major changes in both the national economy and policies implemented for agriculture and livestock sectors. In particular, animal husbandry has been the sector that was considerably affected by these changes (Yalçınkaya, et al., 2006, Cevger et al., 2011).

A number of crops and animal products covered by price support in our country in the 1970s was around 20 , and it decreased to 10 with the effect of the policies implemented in the $1980 \mathrm{~s}$. In this context, exclusion of animal products from the scope of support, especially slaughtering animals and meat has led to the further deepening of problems for production and consumption which was continuing for many years in Turkey. However, the decision of determining the production, supply and demand by the price which would form in market economy conditions, have negatively affected livestock sector in need of support policies (Cevger et al., 2011, TUiK, 2019).

In the livestock sector, the producers faced a semi -monopoly market condition in which no fully competitive market was established without an institutional infrastructure to ensure the functioning of the free market economy system (Cevger et al., 2011). Rural animal breeders were generally smallscale enterprises with poor bargaining power. Therefore evaluation of Turkey's livestock and meat market in free-market conditions was not possible. Thus, both in the 1980 s period and today, animal products' price in rural areas forms in oligopsony market conditions (TUIK, 2019).

Withdrawal of state support from animal products, the formation of animal product prices in the incomplete competition market and additionally continuation of giving supports to plant products caused a further deterioration of socio-economic structure of rural areas and also prevented the interaction between sectors which was an important factor in development (Cevger et al., 2011, TUiK, 2019).

After the year 1980, insufficiency in animal production, the increase in input prices which results in price increase in red meat due to inflation meat has been accepted as a partial scarcity and speculative increases in livestock sector and imports were made in order to balance the market against rising prices, to ensure price stability and to nurture the producer and trade sector. Despite the implementation of this import policy, supply-demand balance and price stability in animal products could not be achieved, sector has entered an "economic vicious circle" and the damage of imports to the sector was understood after years (Cevger et al., 2011, TUIK, 2019).

One of the other wrong practices in Turkey was in the organization of public services. With the DecreeLaw No. 183 issued in 1983 and the Law no. 3202 in 1937, the law regulating agriculture and animal husbandry services with a sectoral approach was abolished, and rural services were reorganized with a functional public organization approach. But since the operational structures, the characteristics of the services and the differences between the sectors are not taken into consideration in this regulation, the reorganization of the Ministry of Agriculture and Forestry has been constantly brought to the agenda since the year 2000 and after.

Initiated liberalization policies within the framework of globalization had significant effects on the livestock sector in Turkey in the early 1990s. State economic enterprises such as Meat and Fish Institution, Dairy Industry Institution and Feed Industry Inc., which are the locomotives and socioeconomic balance elements of the production sector were included in the scope of privatization.

Most of the combines and dairy factories affiliated to the Meat and Fish Institution and the Dairy Industry 
Institution were closed down, and production could not be sustained, and also problems occurred in terms of employment.

Import tax rates were raised in 1997, and the importation of live animals and meat was banned, considering the risk of mad cow disease (BSE).

Pasture law enacted in 1998, which was addressing identification of pasture areas and their protection.

The economic crisis in 2001 caused negative consequences in agriculture and animal husbandry, and as a result of decreasing public supports in the policies implemented, both the number of animals and animal products' production decreased in this period. Credits and financing needs, which are very important elements for the rationalization of production in animal husbandry, could not be adequately met, and incentive measures could not be taken to meet the investment financing need and propel the private sector to production in this field. The share of the livestock sector in total agricultural loans remained around $10 \%$ on average.

The important developments and changes in the agriculture and animal husbandry sector after the year 2003 are as follows;

-Supporting budget was prepared for the development of animal husbandry, and the Agricultural Law No. 5488 was enacted, which was the main source of the policies to be applied in the livestock sector.

- Producer Association Law No. 5200 has been enacted. The aims of this law were to deliver products in conformity with the norms and standards in the market, to take measures to increase the marketing power of the products on the international scale, to plan production according to demand and to improve the product quality.

-Bee Producers Association, Sheep-Goat Breeders Association and Cattle Breeders Association were established with the law No. 5996.

-Practices focusing on the development of the ovine breeding such as supporting, breeding animals by public and herd manager projects were implemented, and rams and goats were distributed in order to increase the productivity in sheep and goats. And also $80 \%$ grant support was provided for animal purchases. - Subsidized loans were extended to meet the financing needs of enterprises, and subsidies were provided as female animals, calves, milk premium, milk quality premium, feed crops and fattening material support (HAYGEM, 2015).

The Meat and Fish Institution, which was included in the scope of privatization as of 1995, was removed from this scope and started to serve as the supporting organization in the year 2005. However, the effectiveness of the institution as an intervention agency in the red meat market decreased comparing the period before 1980. In the following years, Institution has been taken away from its purpose and duties in order to regulate the market with an importer approach.

With the global economic crisis and drought in 2008, rising input prices (oil, feed, etc.) increased production costs of enterprises operating in the agriculture and livestock sector. In parallel with this, increases in general prices of crops and animal products have occurred, but the production sector made losses as a result of not being able to reflect this increase in sales prices.

As a result of the decrease in milk prices and increasing costs, producers disposed of their breeding livestock animals, on the other hand, the price and market instability resulted in an increase in red meat prices and the sector was pressed for money.

The policies implemented in our country until 2010 were generally in the form of import restrictions, tariffs and direct market interventions. As of 2010; the decision was taken for the importation of livestock after prohibition of imports for 14 years showing the reasons such as; increased red meat prices as a result of the decrease in red meat supply, providing red meat at reasonable prices to consumers, raw material supply of the livestock-based industry and the concessions given to the European Union in the previous periods about bovine meat. Within this framework, customs tax rates were reduced and notably imports of butchery animals, breeding animals, fattening animals, ovine animals, carcasses and meat have been made. Imports in the livestock sector which is increasingly ongoing for nine years is being discussed by public opinion in terms of sustainability by the reasons for the destruction caused on the sector and spent foreign currency (Figure 1, Figure 2).

Importer approach in Turkey, which eliminates the production dynamics of agriculture and animal husbandry is extremely wrong for the future of the country. It is seen that tested policies in the past are now on the agenda again (as of 2010); livestock products, which were only $\$ 24$ million in 1982, increased 15 times to $\$ 353$ million over time. Again, fifteen years later, imported animal products (excluding breeding animals) increased approximately tenfold and reached $\$ 2.857 .531 .911$ today (TIGEM, 2018). These numbers show that Turkey is a net importer country in animal products and in some crops and there's no self-sufficiency. 


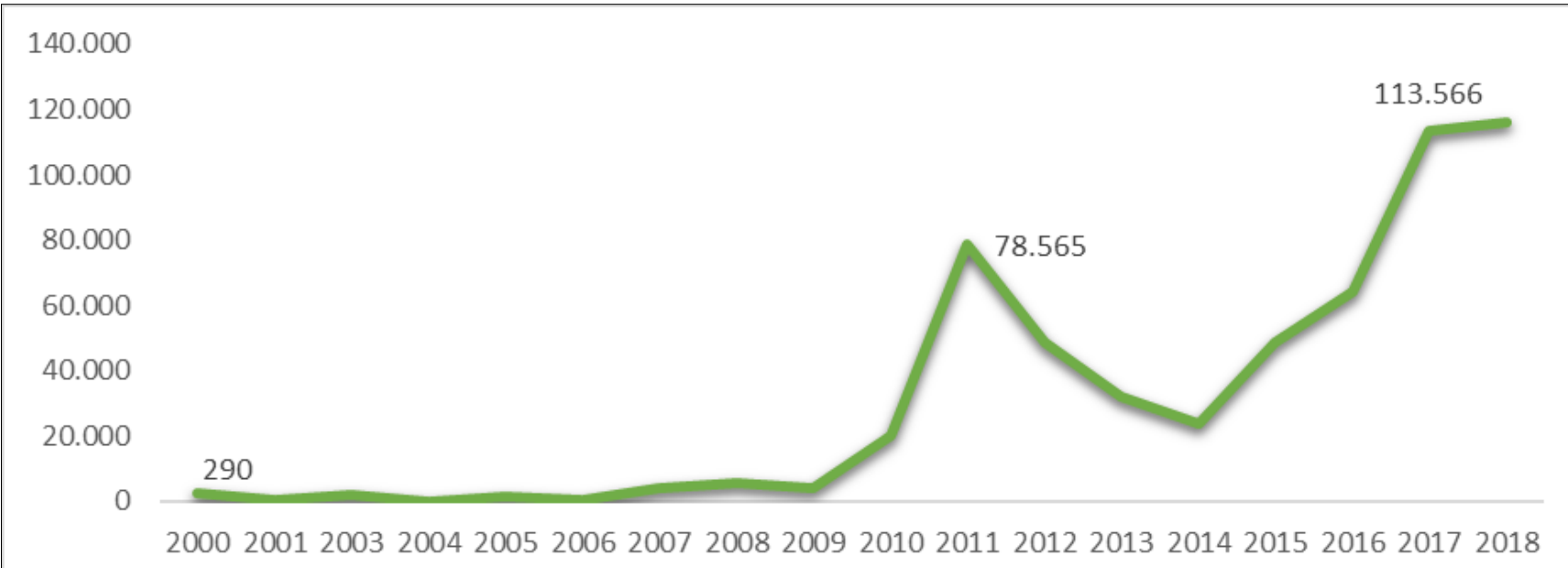

Figure 1. Butchery cattle import by years (heads)



Figure 2. Butchery cattle and beef import by years (ton)

National Dairy Council was established in in 2013. As of 2015, a new regulation has been published which revised the provisions of the pasture law, which was enacted in 1998, and so that the pastures were opened for construction.

When the developments in the livestock sector mentioned in the five-year development plans are examined, it is seen that the targets and realizations in animal production (except poultry meat and eggs) in the 8th and 9th plans are insufficient, the productivity per unit animal cannot be increased sufficiently and the developments aimed at pasture and animal breeding did not occur.

\section{Production and Future of Red Meat}

The production of animal products is an indispensable production area that must be handled within the scope of strategic products. Especially in milk and red meat production, as the main sectors; ensuring self-sufficiency, sustainability and food safety are among the priorities of many countries, particularly in developed countries. On the other hand, it is observed that the policies aimed at preserving the level of living (welfare) of the producers compared to the other sectors (industry and service) and the consumers to consume healthy and high-quality products at the most reasonable price have been sustained and gained importance.

The meat and meat products sector is considered as one of the fastest-growing sub-sectors in the global agriculture and food sectors. In addition to the increase in global meat demand, productivity in production, processing and transportation were also effective in this development.

The contribution of fattening activities to the economy is not limited to red meat production, the by -products obtained from this sector can be used as raw materials in the production process of many sectors (Çiçek, 2002). 


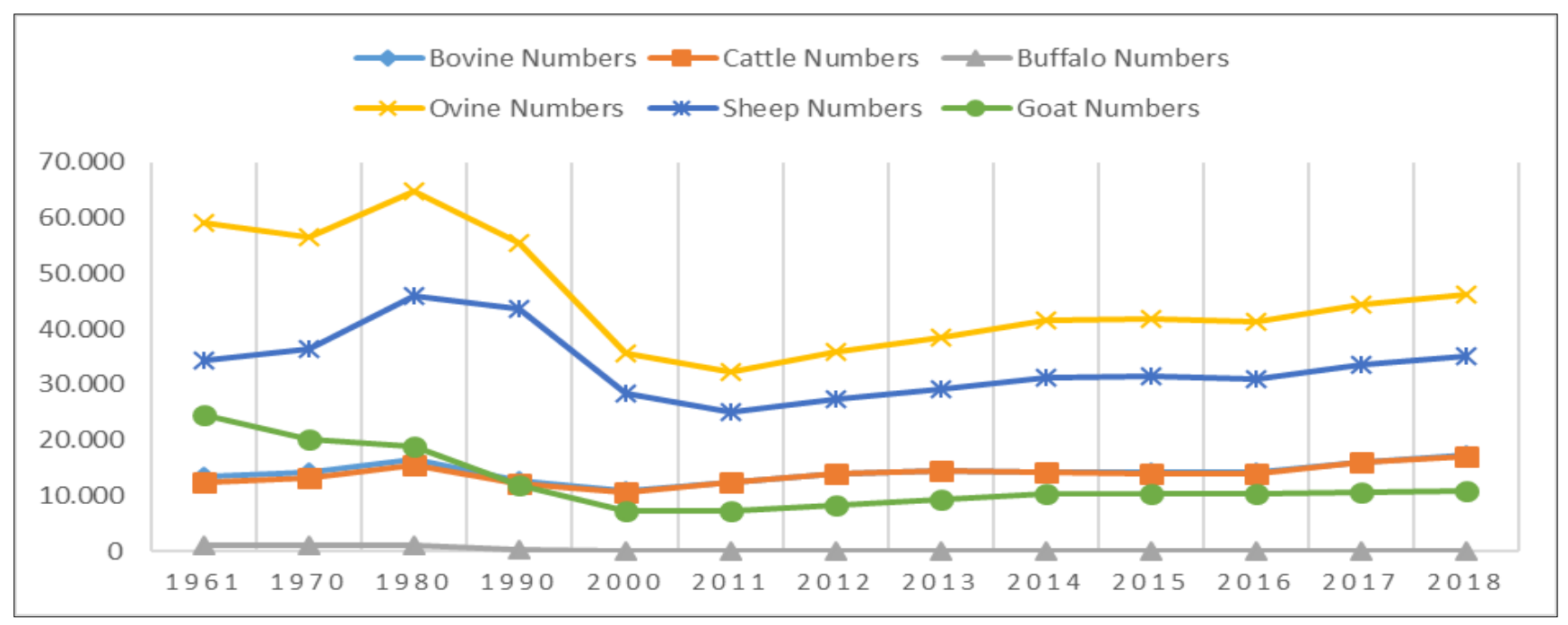

Figure 3. Presence of animal numbers by species and by years (1961-2018)

In our country, the red meat sector meets the demand of meat of approximately 82 million inhabitants, as well as tourists who reach 37 million people annually and approximately 5 million immigrants. The sector is critical because of its place in nutrition and its potential in production.

From the analysis of Figure 3, the number of cattle is 17.043.000 heads, and the number of ovine is 46.117.000 heads, including goats as of 2018. In the cattle population, the percentage of culture breeds is $49 \%, 41 \%$ includes hybrids, and $10 \%$ consists of native breeds.

When Figure 4 is analyzed, the number of slaughtered cattle reached 3.426 .178 heads as of the end of 2018 , while $89.7 \%(1,003,859$ tons) of the total red meat production (1.118.695 tons) was bovine meet at the end of the year.

When red meat consumption per capita in Turkey is compared to developed countries, it appears to be at a lower level. When the consumption of red meat in the last five years is examined, it is seen that the per capita consumption which was $12.4 \mathrm{~kg}$ in 2012 was $12.9 \mathrm{~kg}$ in 2014 and increased to $14.1 \mathrm{~kg}$ in 2017. In 2018, per capita, red meat consumption amounted to $14.84 \mathrm{~kg}$, of which $13.3 \mathrm{~kg}$ was veal. Annual per capita consumption of beef in the USA is $25.8 \mathrm{~kg}, 41.2$ $\mathrm{kg}$ in Argentina, $43.2 \mathrm{~kg}$ in Uruguay and $10.1 \mathrm{~kg}$ in Russia (TEPGE, 2019).

When the average carcass productivity of cattle was examined, it was $215.6 \mathrm{~kg}$ in 2007 and reached $274 \mathrm{~kg}$ in 2017 (UKON, 2019). It should not be overlooked the role of live slaughter animals and fattening animals imported to the country in recent years in the increasing of cattle carcass productivity with breeding activities together.

Development of cattle breeding and cattle meat production is not the solution for red meat supply in the short term. Projects and supports to increase lamb

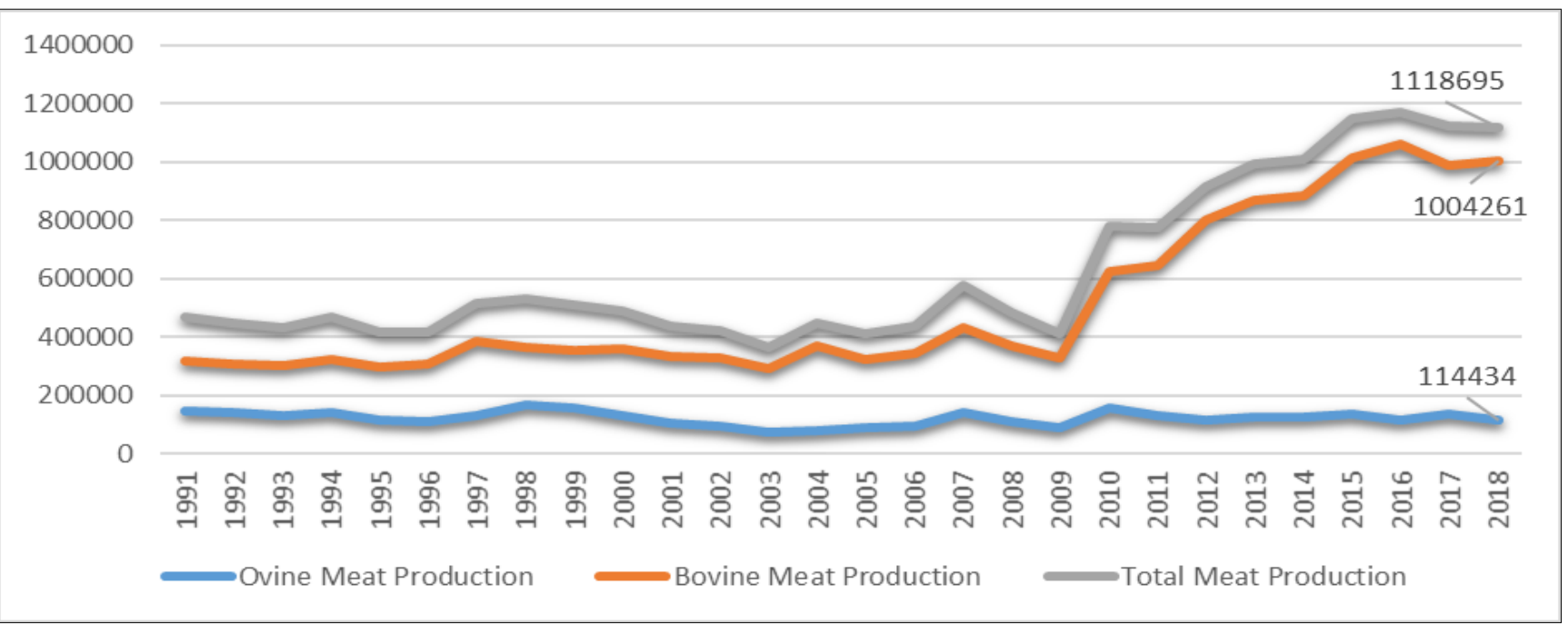

Figure 4. Meat production according to slaughtered animal species and their share in total red meat production 
Table 1. Scale of Cattle Fattening Enterprises in Turkey (2017)

\begin{tabular}{ccccc}
\hline $\begin{array}{c}\text { Cattle fattening } \\
\text { farm-scale } \\
\text { (head) }\end{array}$ & $\begin{array}{c}\text { Number of en- } \\
\text { terprises } \\
\text { (number) }\end{array}$ & $\begin{array}{c}\text { Distribution of enterprises by } \\
\text { scales } \\
\mathbf{( \% )}\end{array}$ & $\begin{array}{c}\text { Animal numbers by } \\
\text { scales }\end{array}$ & $\begin{array}{c}\text { Distribution of animal } \\
\text { existence by scales } \\
\text { (\%) }\end{array}$ \\
\hline $\mathbf{1 - 5}$ & 119.077 & 45,07 & 359.542 & 9,01 \\
$\mathbf{6 - 9}$ & 50.077 & 18,95 & 380.802 & 9,54 \\
$\mathbf{1 0 - 1 9}$ & 48.740 & 18,45 & 705.809 & 25,35 \\
$\mathbf{2 0 - 4 9}$ & 32.942 & 12,47 & 1.011 .701 & 16,69 \\
$\mathbf{5 0 - 9 9}$ & 9.731 & 3,68 & 672.333 & 9,85 \\
$\mathbf{1 0 0 - 1 9 9}$ & 2.683 & 1,02 & 378.362 & 9,48 \\
$\mathbf{2 0 0 - 4 9 9}$ & 775 & 0,29 & 229.429 & 5,75 \\
$\mathbf{5 0 0}$ and above & 205 & 0,08 & 252.440 & 6,33 \\
Total & 264.230 & 100 & 3.990 .418 & 100 \\
\hline
\end{tabular}

production, which is a substitute product, will play an important role in covering this production gap. In this context, it should be aimed to increase the share of ovine livestock in red meat production to $20-25 \%$ in the short and medium-term. On the other hand, studies to create demand for lamb meat; publicity advertising, public service announcements, the proportion of calf, lamb and goat meat in public tenders, as well as the export target within the framework of the research aimed to reduce production costs gain importance.

In red meat production, within the consideration of the supply characteristic of the "production cycle"; it is important to develop necessary livestock policies in other production sub-sectors; such as turkey, duck, goose, rabbit etc. in order to create demand and to encourage consumption of meat.

It is observed that the supports applied to animal husbandry have increased, especially in the last ten years. The share of animal husbandry from total agricultural support was $4.4 \%$ in 2002 , and this ratio reached $28.3 \%$ in 2018, which is a positive development for the sector, and is expected to be around 31\% in 2019 (TEPGE, 2019).

Despite all these supports and regulations related to the animal husbandry, it is observed that targeted production increases cannot be achieved. The involvement of more than one institution in the implementation of the support policies, the difference of the programs and objectives of the institutions and the lack of coordination in the policies couldn't cause the foreseen developments in animal husbandry. On the other hand, the reason why the support for animal husbandry is insufficient and the effectiveness is not at the desired level is the failure to solve the structural problems in the sector with the wrong agricultural policies.

After the economic crisis in 2008, the bottleneck in the meat and milk sector, red meat supply shortage due to increase of population and demand level in recent years and increasing red meat prices in market has led to the importation of fattening and slaughter animals and carcass meat. These were palliative measures for the purpose of meeting the raw material demand for industry and provide cheap meat for consumers. However, after the import red meat prices have not been stabilized with the deliberate policies, the supply of cheap meat to the consumer has been failed.

There are around 3 million enterprises operating in the agricultural sector, $67 \%$ of them are specialized in polyculture (plant and animal production), $30 \%$ in agriculture and the remaining $3 \%$ are specialized in animal husbandry. The fact that the specialization in the farms is inadequate, in general small-scale, disorganized family farms with traditional production reduces production increase and efficiency.

In the examination of the Table 1 , in total, there are 264.230 cattle fattening enterprises in Turkey. $64.02 \%$ of these enterprises are small scale enterprises with the animal number under ten heads. In cattle fattening, the share of 50 heads and above enterprises in the total farms is only $5.07 \%$. On the other hand, these enterprises, which are classified as large-scale, have $38.41 \%$ of total fattening cattle with 1.532.564 head cattle. 
Animal production models suitable for economies of scale should be considered as opportunities, especially in areas where the country has a comparative advantage.

On the other hand, it is known that exporting countries that are producing low-cost meat have the advantage of competing in world trade. In Turkey, meat production takes place at a high cost. Due to this, it is unable to find a chance to compete on a global scale, and Turkey falls into countries that import red meat and butchery fattening animals.

Especially in recent years, the increase in production costs due to inflation, foreign exchange and input prices could not be reflected in sales prices. Farmers, whose profitability levels drop due to uncertainty and unfair competition in the market, are withdrawn from the production area, and this situation creates a negative environment in terms of sustainability in production. The purchase prices of butchers announced by Meat and Dairy Institution did not take into consideration the production costs and meat-feed parities and the red meat prices were suppressed by the deliberate policies.

In parallel with the increase in the scope and quantity of imports, the instability and unfair competition in the meat market has been reported that around 20 thousand cattle fattening enterprises have shut down or stopped the operation in the last two years. In this process, it is necessary to determine the needs of the enterprises that stopped operation and to encourage and support them in order to start fattening and production under the controlled conditions of flocks that will consist of right animal breeds.

When we look at the fattening system in our country, it is seen that it is based on coarse feed consisting mainly of cereals, pulp and other byproducts. The $40-45 \%$ of compound feed produced in Turkey depends on imported feedstuffs. According to this situation, feed costs increase, and this adversely affects the cost of meat production. The fattening method based on concentrated eating is expensive. In Europe, Australia and some South American countries, the main reason why the cost of animal production is cheap compared to our country is the availability of abundant and cheap roughage. Red meat production costs can be lowered as long as the roughage rate in animal fattening is increased according to the concentrate rate. For a rational fattening and cheaper meat production, the ratio of roughage used in fattening must be increased, and the dependence on import should be reduced, and self-sufficiency must be ensured.

If sufficient success is not achieved in a country in terms of race/genotype, healthy environment, proper feeding and herd management, neither the desired targets in milk or meat production can be achieved. Since the desired success cannot be achieved in these four important issues, red meat production costs are very high in our country. A production model to specialize in the production of red meat has also not been adopted. Current technical and economic data are insufficient in order to calculate feed cost and production planning for enterprises.

When the beef carcass/feed parity which is an important ratio in cattle fattening in line with the profitability and costs of the producer is examined, in 2015, the farmer received $30.2 \mathrm{~kg}$ fattening feed for 1 $\mathrm{kg}$ carcass; in 2016, it was able to take $30.7 \mathrm{~kg}$ and $28.3 \mathrm{~kg}$ in 2017. In 2018, $23.89 \mathrm{~kg}$ of fattening feed could be obtained for $1 \mathrm{~kg}$ of calf carcass. At this point, the high rate of increase in feed prices reduces this parity to below 20 levels. The reason for the decrease in carcass/feed parity is that the increase in feed prices is higher than the increase in carcass prices. Currently, since the cost of unit carcass production in cattle fattening is higher than the carcass sales income, the profit takes the negative value, and the producer makes a loss in the current conditions (Aral, 2019, TEPGE, 2019).

\section{General Evaluation}

Animal husbandry has become an industry in developed countries and has become an integral part of the economy. This situation reveals that agriculture and therefore, animal husbandry is a strategic sector that needs to be developed at the national level (TIGEM, 2018).

In our country, a structure based on imports in red meat has some disadvantages in terms of rural economic development and sustainability in production and creates unfair competition by disrupting animal product markets.

Considering the national interests; measures should be taken in the short term, to protect the domestic producer and prevent unfair competition in the importation of animal and animal products, feed raw materials and additives. However, customs duties should be regulated within this framework, and the decision to import live animals and red meat should be completely abandoned in the medium term (HAYGEM 2018a, UKON, 2019).

Policies and practices that will allocate confidence in the sector in terms of market balance, price formation, marketing structure that considers production and sales costs, industry-production integration, stability and competitiveness should be implemented effectively and quickly to increase red meat production, to ensure self-sufficiency and sustainability in Turkey. 
With the policies to be taken on a macro basis to solve the technical and economic problems of the livestock sector; structural changes such as ensuring market stability and increasing productivity have to take place. By this time various supports have been made to the sector in different forms, periods and amounts. However, the supports implemented without solving the structural problems were not sufficient and effective in reaching the targeted level of the sector.

The classification of the enterprises operating in the agricultural sector according to their production forms and characteristics may reveal which product production is supported in particular. It will be possible to make comparative analyses of different sized enterprises in order to determine where market trends, policies, and economic conditions are more influenced than where and at what point of a particular entity and to help researches to monitor market conditions and evaluate the possible impact of policymakers.

The real policy to support animal husbandry should be to ensure that product/feed price ratios continue to maintain profitability in animal husbandry activities. In the modern sense, livestock enterprises in an optimum scale, which are integrated with forage crops will be inevitable for our country in the future.

In order to improve the technical and economic efficiency of fattening enterprises, a general production planning and periodic cost calculations will be able to help to see the way through the entire production period. It is important to focus on practices such as intervention purchases and contractual fattening with the industry in order to continue its activities with guaranteed purchase prices including production costs and profit to not have any problems in the marketing of butchery animals and meat (Aral, 2019).

Due to the contribution of the livestock sector to the national economy, a large number of people have demand for services from the public sector. Meeting these demands effectively will enable the livestock sector to develop and solve most problems. There is a need for a new restructuring and reorganization of the veterinary services provided by the public, especially in rural areas.

It is obligatory to consider the livestock services in the public sector on a sectoral basis by taking into account the EU harmonization and developed country examples. Considering the nature of animaloriented services, an effective structuring with a chain of command should be established in the ministry. In this framework, the quality and efficiency of veterinary services to be taken to rural areas will increase, and service cost will be reduced, effectiveness in the struggle against animal diseases will be ensured, and multi-headed decisions will be avoided in animal husbandry.

In order to increase red meat production, it would be an effective approach to link organized animal husbandry regions with public sector and to take similar initiatives to the previous projects (contract model) of the Meat and Milk Institution. Within the framework of this model, it will be possible to achieve market stability and sustainability by creating purchase prices that take into account the producer's production costs

In the improvement of the meat market; the development of marketing infrastructure and the encouragement of producer organization will contribute to the solution of the problems. On the other hand, studies and researches aimed at increasing productivity and quality in these markets, determining product and cutting standards, increasing product diversity and establishing the quality-price relationship will also increase competitiveness.

The milk and red meat sub-sectors are complementary to each other and have a strong relation (input-output). Therefore it is also important to establish a rational production and marketing organization in the dairy sector, to prevent periodic price fluctuations, to cooperate with the administrative structures operating in the meat and milk markets, and to ensure and maintain the regulation of market conditions effectively.

The enterprises operating in the field of animal husbandry are under the economic grip of the sellers and buyers, who are limited in number and dominate the prices, both in the production stage (feed, medicine, etc.) and in the supply stages. In this respect, it is necessary to support the producer organization by the state to solve the problems.

In Turkey, the production of some crops has decreased, and agricultural areas have not been planted in recent years. Incentives should be given to increase the production of forage crops and roughage as an alternative product to these areas which are out of production. On the other hand, in regional projects (GAP, DAP, KOP, etc.), supporting the production of forage crops in order to cover the roughage gap may make an important contribution.

Required precautions should be taken to extend and develop insurance services in order to protect the producer by providing adequate amounts of agricultural insurances, especially about animal diseases and economic losses. 


\section{References}

Aral, Y. (2019, Nisan, 14-17). Türkiye'de Sığır Besiciliğinin Temel, M. (2015). Atatürk Dönemi Hayvanclık Politikası. Yapısal ve Ekonomik Yönden Değerlendirmesi. 1. Muğla Üniversitesi Sosyal Bilimler Enstitüsü Dergisi, Uluslararası Çiftlik Hayvanları Hekimliği Kongresi, (24), 1-33.

Fethiye/ Türkiye.

Cevger Y., Aral Y., Sakarya E. (2011). Hayvancilık TiGEM, (2018). 2017 Yılı Hayvancilık Sektör Raporu. Ekonomisi. Eskişehir, Türkiye: Açıköğretim Fakültesi Yayını.

Çiçek, H. (2002). Afyon ili sığır besiciliği işletmelerinde kârlııı ve verimlilik analizleri. Ankara Üniversitesi Sağlık Bilimleri Enstitüsü, Doktora Tezi, Ankara, Türkiye

Erk. N. (1973). Türkiye Cumhuriyetinin Illk 50 Yılında (1923 -1973) Veteriner Hekimlik Öğretiminin Gösterdiği Gelişmeler, TR: Ankara Üniversitesi Basımevi.

HAYGEM (2015). Kırmızı Et Stratejisi. Tarım ve Orman Bakanlığı, Hayvancılık Genel Müdürlüğü. Erişim:https:// www.tarimorman.gov.tr/HAYGEM/Belgeler/Hayvanc\% C4\%B1|\%C4\%B1k/K\%C4\%B1rm\%C4\%B1z\%C4\%B1\% 20Et\%20Stratejisi.pdf Erişim Tarihi: 05.08.2019

HAYGEM (2018). Büyükbaş ve Küçükbaş Hayvancılık Çalıştay Sonuç Raporu, Antalya.

Kazgan, G. (1977). Tarım ve Gelişme. İstanbul. Türkiye: İstanbul Üniversitesi İktisat Fakültesi Yayınları.

TEPGE (2019). Tarım Ürünleri Piyasaları, Dana Eti. Erişim: https://arastirma.tarimorman.gov.tr/tepge/Belgeler/ PDF\%20Tar\%C4\%B1m\%20\%C3\%9Cr\%C3\%BCnleri\% 20Piyasalar\%C4\%B1/20190cak\%20Tar\%C4\%B1m\%20\% C3\%9Cr\%C3\%BCnleri\%20Raporu/2019-Ocak\%20Dana\% 20Eti.pdf, Erişim Tarihi: 04.08.2019

Erişim: https://www.tigem.gov.tr/WebUserFile/ DosyaGaleri/2018/2/a374cc25-acc1-44e8-a54663b4c8bce146/dosya/2017\%20TIGEM\% 20HAYVANCILIK\%20SEKTOR\%20RAPORU.pdf Erişim Tarihi: 03.08.2019

TÜiK (2019). Türkiye İstatistik Kurumu, Hayvancılık İstatistikleri, Türkiye'de Kesilen Hayvan Türlerine Göre Elde Edilen Et Üretim. Türkiye-2000 Hayvancılık Kongresi Kitabı (2000). Ankara, Ankara Ticaret Borsası.

UKON (2019). Kırmızı Et Sektörü 2018 Yılı Değerlendirme Raporu. Erişim: http://www.ukon.org.tr/pdf.aspx Erişim Tarihi: 02.08.2019

Yalçınkaya, N., Yalçınkaya, M. H., \& Çilbant, C. (2006). Avrupa Birliği'ne yönelik düzenlemeler çerçevesinde Türk tarım politikaları ve sektörün geleceği üzerine etkisi. Yönetim ve Ekonomi: Celal Bayar Üniversitesi iktisadi ve Idari Bilimler Fakültesi Dergisi, 13(2), 97118. 